\title{
John H. Cochrane and John B. Taylor (editors): Strategies for monetary policy
}

\author{
Hoover Institution Press, 2020
}

David Wilcox ${ }^{1}$

Published online: 12 January 2021

(c) National Association for Business Economics 2021

The papers in this fine volume, assembled by editors John Cochrane and John Taylor, were written "to help inform an important review of monetary policy undertaken by the Federal Reserve in 2019." "In the short time since the volume was finalized, COVID-19 has exploded onto the world scene, causing vast medical harm and heartache as well as financial and economic disruption of historic proportions. In addition, the Fed has unveiled major portions of the results of its framework review. The first of these events dramatically altered the conduct of monetary policy in the near term; the second provides a view into the basic principles that the Fed believes should guide the conduct of monetary policy now and over at least the next few years.

A striking aspect of the volume-mostly implicit rather than explicit-is the extent to which views about the appropriate conduct of monetary policy have converged between previously warring sides over the past four or five decades. For example, transparency is now universally recognized as constructive. Gone are the days where opacity was seen as a necessary element of monetary policy if central banks were to have any real effect. As recently as 1987, Alan Greenspan reportedly told a subcommittee of the US Congress that "If I seem unduly clear to you, you must have misunderstood what I said." Greenspan himself began turning the ship on that belief, with the inauguration of post-meeting announcements of policy changes beginning at the FOMC's February 1994 meeting. Ben Bernanke took the transparency agenda much further-for example, with the inauguration of quarterly press conferences in 2011 and the adoption by the FOMC of the "Statement on Longer-Run Goals and

David Wilcox

DWilcox@PIIE.COM

1 Peterson Institute for International Economics, Washington, DC, USA
Monetary Policy Strategy" in 2012. Chairs Yellen and Powell have continued in the same direction.

A related development is that systematic, predictable, behavior also is seen as essential to promoting the effectiveness of policy. While no central bank is setting its policy rate in mechanical adherence to a conventional policy rule, there is no longer any serious dissent from the view that central banks need to respond to changing circumstances in a manner that is empirically grounded, explainable to the public, and clearly aimed at promoting attainment of the central bank's monetary policy objectives. Adherence to the principle of systematic behavior is all the more crucial in a low- $r^{*}$ world. Systematic behavior-taking the form of a promise by the central bank to keep its policy rate "lower for longer"- -represents one of the few remaining tools available to policymakers looking to recoup some of the policy space they have lost as a result of the greater proximity of the effective lower bound.

It is interesting to consider how this substantial degree of convergence was achieved. Perhaps part of the answer is that the two sides were never as far apart as it seemed when the debate was most heated. Economists at the more activist end of the spectrum - in an earlier era they might have identified as "saltwater" in lineage - continue to defend the view that a central bank must have the flexibility to take into account the unique circumstances of the moment when making policy decisions in real time. But implicitly, at least, most if not all would readily agree that discretion will mainly be confined to the margins and nuances of the actions of a central bank. For their part, most economists toward the more restrained end of the spectrum-probably referred to in a previous era as "freshwater" in lineage—do not literally

\footnotetext{
${ }^{1}$ Page ix. For the Federal Reserve's own description of the framework review, see https://www.federalreserve.gov/monetarypolicy/ review-of-monetary-policy-strategy-tools-and-communications.htm.
} 
advocate conducting monetary policy according to a simple algebraic formula.

While recognizing the convergence, it is also worth noting that the rules versus discretion debate lives on to some degree; witness the two dissents from the FOMC's September 2020 statement-one by President Kaplan of Dallas, who preferred that future committees be left with greater freedom to respond to the particular circumstances of the moment; the other by President Kashkari of Minneapolis, who preferred that the committee bind itself more tightly to a promise not to tighten the stance of policy prematurelywhich, he argues, the committee did beginning in late 2015, before inflation had durably been restored to a position of fluctuating around its 2 percent target.

Despite the extent of convergence, there are at least four key respects in which views expressed in the book are at odds with the current center of gravity of policymaker thinking (recognizing, as illustrated by the Kaplan and Kashkari dissents, that policymakers are hardly monolithic in their views). First, skepticism of the efficacy of large-scale asset purchases (LSAPs) is a recurrent theme of the book (such skepticism being expressed by Andrew Lilley and Kenneth Rogoff, Andrew Levin in his discussion of Lilley and Rogoff, James Hamilton, and Peter Fisher). Nonetheless, LSAPs remain a core tool of the Federal Reserve when the funds rate is pinned at the effective lower bound. As of this writing, the Fed continues to purchase approximately $\$ 80$ billion per month of Treasury securities and approximately $\$ 40$ billion per month of mortgage-backed securities; moreover, the expressed rationale for such purchases has morphed from market calming to include greater emphasis on macroeconomic accommodation, and the FOMC in each of the past several post-meeting statements has declared its intention to continue such purchases "over coming months ... at least at the current pace."

In contrast to the skepticism of LSAPs, there is a marked enthusiasm in the book (stated most vigorously by Lilley and Rogoff) for negative interest rates. Lilley and Rogoff recognize that substantial regulatory and other barriers would have to be removed first, and that a necessary step probably would be to take steps "to stop people from holding large amounts of cash." One aspect of the COVID experience may be relevant here: A surprisingly large segment of the US population have refused - and continue to refuse- to wear masks, and indeed see mask mandates as infringements on their fundamental liberties. One can only wonder how kindly such folk will take to being prohibited from holding physical cash and being forced to hold e-currency with negative rates of return.

While the world of low "normal" interest rates inescapably is a world of unhappy choices, it is worth pondering how large a part of the solution negative rates could be. In simulations that David Reifschneider and I conducted
(Reifschneider and Wilcox 2020), we assumed—based on the track record of its past behavior-that the Fed would want to cut the federal funds rate by about 500 basis points in response to a historically typical recession, and of course would want to cut by much more in response to a historically severe recession. ${ }^{2}$ If the economy goes into recession from a neutral position (with output having been at potential and inflation having been at target, and the funds rate therefore having been at its neutral nominal level), much less than 500 basis points of room for rate cutting would be available —only 200 basis points if the neutral real rate is 0 percent, and 250 basis points if the neutral real rate is 0.5 percent. Despite the popular resistance that surely would accompany them, negative rates may conceivably be part of the solution at some point in the future, but given that even Switzerland-the country that has gone deepest into negative territory - has taken them only as low as -75 basis points, it is hard to envision negative rates playing more than a partial role in restoring the policy space that has been lost to the decline in $r^{*}$.

A third key area of disagreement between the center of opinion in the book versus the predominant view among policymakers pertains to characterization of departures from rules as policy mistakes. Certainly yes, this is the case regarding the 1970s, when a policy that was excessively lax allowed inflation to become dangerously high, leading to the necessary but hugely costly twin recessions of 1980 and 1981-82. More generally, though, this identification is a bit difficult to swallow, given the extent to which-as Cochrane, Taylor, and Volker Wieland (CTW) document in their paper-different rules deliver different policy prescriptions. One can certainly look at the laxness of policy relative to rules during the first decade of this century (see CTW, Figs. 5.1 and 5.2) and declare that the ensuing financial crisis proves that monetary policy erred. But a more compelling interpretation is that insufficient attention was paid to the buildup of financial imbalances, that such imbalances are not an inescapable feature of low-rate eras (if they are, then we are in for rough times in coming decades), and that the better lesson to take away from this experience is the importance of stepped-up surveillance of financial conditions as well as the imperative to improve the toolkit of macroprudential policymakers.

These areas where the views of the book depart from those of current policymakers are not shortcomings of the book. Rather, they underscore the fact that not all is settled in the world of monetary policy, and much fruitful work

\footnotetext{
${ }^{2}$ See "A Program for Strengthening the Federal Reserve's Ability to Fight the Next Recession," by David Reifschneider and David Wilcox, March 2020, Peterson Institute for International Finance, https:// www.piie.com/system/files/documents/wp20-5.pdf.
} 
remains to be done. Just as much progress has been made in the roughly 40 years since the landmark introduction of Taylor's 1993 rule, much progress can be hoped for in the years to come.

Overall, Messrs. Cochrane and Taylor have assembled a useful collection of papers expressing a range of views and pointing to a plethora of areas requiring future research and discussion with policymakers. For that, they and their author and discussant colleagues deserve our thanks and appreciation.

Finally, a note on a challenge facing all of economics, not unique to this volume. Among the contributors to this volume, there were, to the best of my ability to assess, 4 women and 32 men. The representation of persons of color was scant and may have been non-existent. The narrow range of backgrounds, life experiences, and personal characteristics embodied among the contributors stands as a challenge to the field. We all know that macroeconomics and monetary policy entail much more than eigenvalues and stochastic simulations. Among many other considerations, monetary policy affects different members of society differently, in ways that inevitably require policymakers to make tough trade-offs among competing considerations. Until we get the representation problem addressed to a much more satisfactory degree, our collective ability to provide a truly satisfactory analysis of the important issues addressed in this volume will be impeded.

\section{Reference}

Reifschneider, David, and David Wilcox. 2020. A Program for Strengthening the Federal Reserve's Ability to Fight the Next Recession. Peterson Institute for International Finance. https:// www.piie.com/system/files/documents/wp20-5.pdf

Publisher's Note Springer Nature remains neutral with regard to jurisdictional claims in published maps and institutional affiliations. 